\title{
Advertisement call and female sexual cycle in Uruguayan populations of Physalaemus henselii (Anura, Leiuperidae)
}

\author{
Raúl Maneyro ${ }^{1,2}$, Diego Núñez ${ }^{1}$, Claudio Borteiro ${ }^{3}$, Marcelo Tedros $^{4} \&$ Francisco Kolenc $^{5}$
}

1. Sección Zoología Vertebrados, Facultad de Ciencias, Universidad de la República, Iguá 4225, Montevideo 11400, Uruguay. (rmaneyro@fcien.edu.uy)

2. Museu de Ciências e Tecnologia and Faculdade de Biociências, Pontifícia Universidade Católica do Rio Grande do Sul, Brasil.

3. Río de Janeiro 4058, Montevideo 12800, Uruguay.

4. China 2202, Montevideo 12800, Uruguay.

5. Cátedra de Bioquímica y Biofísica, Facultad de Odontología, Universidad de la República, Montevideo 11600, Uruguay. Cátedra de Fisiología, Facultad de Odontología, Universidad Católica del Uruguay, Montevideo 11200, Uruguay.

\begin{abstract}
Physalaemus henselii (Peters, 1872) is a little known leiuperid frog that has not been studied since the 1960's. Herein, we redescribe its advertisement call, and assess the female sexual cycle and the reproductive period on the basis of the macroscopic analysis of the ovaries and field observations. The Ovarian Size Factor (OSF) was calculated. The study was made in Departamento de Rivera, northern Uruguay. The advertisement call consists of short $(177 \pm 21 \mathrm{~ms})$, multipulsed $(20 \pm 3$ pulses/note) notes, with a note repetition rate of $1.57 \pm 0.13$ notes/s. Physalaemus henselii has a female sexual cycle with unimodal distribution of gravid females, which are present from February to September. The OSF and the ratio "females with mature oocytes / females without mature oocytes" reached the highest values from April to June. The number and size of oocytes were positively correlated with female size. The smallest female (SVL $=18.94 \mathrm{~mm}$, weight $=0.78 \mathrm{~g}$ ) with mature oocytes was found in July. The observed sexual cycle with a single annual reproductive period during the cold season (autumn and early winter), is an uncommon fact for anuran species in the region.
\end{abstract}

KEYWORDS. Amphibia, Anura, Physalaemus, advertisement call, sexual cycle.

RESUMEN. Canto de anuncio y ciclo sexual femenino en poblaciones uruguayas de Physalaemus henselii (Anura, Leiuperidae). Physalaemus henselii (Peters, 1872) es un pequeño leiupérido que no ha sido estudiado desde los años 60. Aquí redescribimos su canto de anuncio, y determinamos su ciclo sexual femenino y el período reproductivo en base al análisis macroscópico de los ovarios y de observaciones de campo. Fue calculado el Factor de Tamaño Ovárico (FTO). El estudio fue realizado en el Departamento de Rivera, norte de Uruguay. El canto nupcial consiste en notas cortas $(177 \pm 21 \mathrm{~ms})$ y multipulsadas $(20 \pm 3$ pulsos/nota), con una tasa de repetición de notas de $1.57 \pm 0.13$ notas/s. Physalaemus henselii tiene un ciclo sexual femenino con distribución unimodal de hembras maduras, las que están presentes de Febrero a Setiembre. El FTO y la tasa "hembras con ovocitos maduros / hembras sin ovocitos maduros" alcanzó los valores más altos desde Abril a Junio. El número y tamaño de los ovocitos estuvieron correlacionados positivamente con el tamaño de las hembras. La hembra más pequeña $(\mathrm{SVL}=18.94 \mathrm{~mm}$, masa $=0.78 \mathrm{~g}$ ) con ovocitos maduros fue encontrada en Julio. El ciclo sexual observado, con un solo periodo reproductivo anual durante la estación fría (otoño e invierno temprano), constituye un hecho poco frecuente en las especies de anuros de la región.

PALABRAS CLAVE. Amphibia, Anura, Physalaemus, canto de anuncio, ciclo sexual.

The reproductive cycles in amphibians are under hormonal and environmental control, which produce particular patterns (DUELLMAN \& TRUEB, 1994). In species of temperate regions, the trend toward seasonal breeding is reinforced and correlated with climatic cycles in temperature and precipitation (JøRGENSEN, 1992). This seasonal pattern is evident in the gonadal annual cycle, in which activity and resting periods are alternated (JøRGENSEN, 1992).

The genus Physalaemus Fitzinger, 1826 currently comprises 41 species (Frost, 2007) and it is widely distributed in the Neotropical region. Physalaemus henselii (Peters, 1872) was included in the P. henselii species group together with P. fernandezae (Müller, 1926) and $P$. riograndensis Milstead, 1960 (NASCIMENTO et al., 2005), and it is known from Uruguay, state of Rio Grande do Sul (Brazil) and eastern Entre Ríos Province (Argentina) (CEI, 1980; Frost, 2007).

Vocalizations in Physalaemus were firstly studied by BARRIO $(1964,1965)$, who used them to identify cryptic species. He also stated the diversity in the advertisement calls among the species of this genus, which he classified into four types (BARRIO, 1965). Barrio's recordings of the advertisement call of $P$. henselii in southern Uruguay were decisive for the proper identification of this species, previously confused with Physalaemus fernandezae (BARrio, 1953, 1964). Recently, Pimenta \& CRUz (2004) recognized the difficulty in making comparisons of acoustic parameters of the advertisement calls reported for different Physalaemus species, because most descriptions were made in the 1960's, when the analyses were limited by the available technology.

The knowledge about reproductive biology in the genus Physalaemus is scarce and limited to few species (BARRIO, 1964, 1965; BoKermanN, 1962; CARdoso, 1981; Cei, 1980; Heyer et al., 1990; Haddad \& Pombal, 1998; NAscimento et al., 2001; Wogel et al., 2002; Nomura et al., 2003; Giaretta \& Menin, 2004). Based on field observations, a double reproductive period was proposed for $P$. henselii, with one episode in winter and another in summer (BARRIO, 1964).

The purpose of this study is to redescribe the advertisement call of $P$. henselii and compare it with previous records. In addition, the female sexual cycle and 
the reproductive period are assessed on the basis of the macroscopic analysis of the ovarian and field observations.

\section{MATERIAL AND METHODS}

Specimens examined in this study are housed in the Vertebrate Zoology Collection, Facultad de Ciencias, Universidad de la República, Uruguay (ZVCB).

The advertisement calls were recorded at Pueblo Madera, in a wet grassland, on 2 May 2003, at 22:45h $\left(\right.$ ZVCB 11180 and 11181 ; air temperature $=7^{\circ} \mathrm{C}$, water temperature $=14^{\circ} \mathrm{C}$ ) and on 3 May 2003, at 20:40h (ZVCB 11182 and 11183 ; air temperature $=8^{\circ} \mathrm{C}$, water temperature $\left.=16^{\circ} \mathrm{C}\right)$. A TCM-20DV Sony tape recorder and a dynamic range $20 \mathrm{kHz}$ microphone were used for recording calls in the field. The recordings were digitalized with a Roland UA-100 analogic-digital converter, with $44.1 \mathrm{kHz}$ sample frequency and 16 bit resolution, using Sound Forge 5.0 software. This software was used to generate oscillograms and spectrograms (FFT 1024 points). A tennote sequence was analysed for each individual $(\mathrm{N}=4$ individuals).

The female sexual cycle was studied on a sample collected at Establecimientos El Palenque, Rocha, Vázquez and Trinidad, Route 27, 20km southeast from Rivera city. The frogs were caught with pit-fall traps from March 2001 to February 2002. They were weighted with a digital scale $(0.01 \mathrm{~g})$, measured (snout-vent length) with a digital calliper $(0.1 \mathrm{~mm})$ and sexed by gonadal examination. Ovaries and oviducts were removed, and total number of oocytes and the diameter of a subsample ( $\mathrm{N}=10$ for each ovarian) were recorded for each female. The Ovarian Size Factor (OSF) (DuELLMAN \& CRUMP, 1974; BAsso, 1990) was calculated on the overall sample ( $\mathrm{N}=63$ ) and on each monthly sample, as follows: OSF = ND x OD / SVL, where ND is the average number of mature oocytes, OD the average diameter of oocytes, and SVL the average snout vent length. A regression between snout-vent length (SVL) and number of mature oocytes was computed to detect significant size effects. The sex ratio (number of females/number of males) was calculated for each month. Values are given as mean $\pm \mathrm{SD}$ with range between brackets.

\section{RESULTS}

Advertisement call. The advertisement call of $P$. henselii consists of a repetition of notes that to the human ear sounds like a cricket call (Fig. 1). The notes have a mean duration of $177 \pm 21(137-211) \mathrm{ms}$; they have a pulsed structure, with $20 \pm 3(13-28)$ pulses/note and a rate of $113 \pm 18(76-143)$ pulses/s; the first pulses being of less amplitude and faster than the last ones. The power spectrum shows two main bands of maximum acoustic emission, the most important ranges from $1,995 \pm 217 \mathrm{~Hz}$ to $5,973 \pm 501 \mathrm{~Hz}$, with a dominant frequency of $3,706 \pm$ $132 \mathrm{~Hz}$, and the second one ranges from $5,973 \pm 501 \mathrm{~Hz}$ to $9,094 \pm 528 \mathrm{~Hz}$, with a dominant frequency of 7,277 \pm
$265 \mathrm{~Hz}$. The mean note repetition rate is $1.57 \pm 0.13(1.45-$ $1.73)$ notes/s. The gap between two consecutive notes is $462 \pm 90(358-754) \mathrm{ms}$. These frogs vocalize semi submerged, with their body inside the water, hidden among gramineous tufts, being very difficult to locate.

Female sexual cycle. Mean weight and SVL for females with mature oocytes $(\mathrm{N}=63)$ were $1.14 \pm 0.25$ $(0.65-2.10) \mathrm{g}$ and $23.1 \pm 1.5(18.8-27.7) \mathrm{mm}$ respectively. The mean number of mature oocytes for the right ovarian was $172.33 \pm 65.83(40-361), 124.62 \pm 54.36(29-270)$ for the left, and $148.48 \pm 57.82$ for both. The number of mature oocytes for an individual (both ovaries) was $296.95 \pm$ 115.64, the minimum was 70 (a female caught on June, SVL $=18.9 \mathrm{~mm}$ ) and the maximum was 631 (a female caught on April, SVL $=27.7 \mathrm{~mm}$ ). The smallest frog with mature oocytes reached $18.9 \mathrm{~mm}$ and $0.78 \mathrm{~g}$, and was caught on July. The regression between SVL and number of mature oocytes shows a significant slope $\left(R^{2}=0.49 ; p<0.001\right.$, Fig. 2).

Females with mature oocytes appeared from February to September (except March, when no females were caught). The highest values of OSF were reached from April $(\mathrm{OSF}=62.3)$ to June $(\mathrm{OSF}=52.4)$. These highest values were coincident with highest values for the ratio "females with mature oocytes/females with immature oocytes" (April =18/0, May =29/0 and June =9/0). From October to January, only females with immature oocytes were caught (Tab. I, Fig. 3).

The sex ratio reached its maximum (2) during December, but in this month only immature females were found (so this ratio could be an artifact), the second highest value occurred in May (1.53), when only mature females were present in the sample (Tab. I). Froglets were caught mainly in November and December.
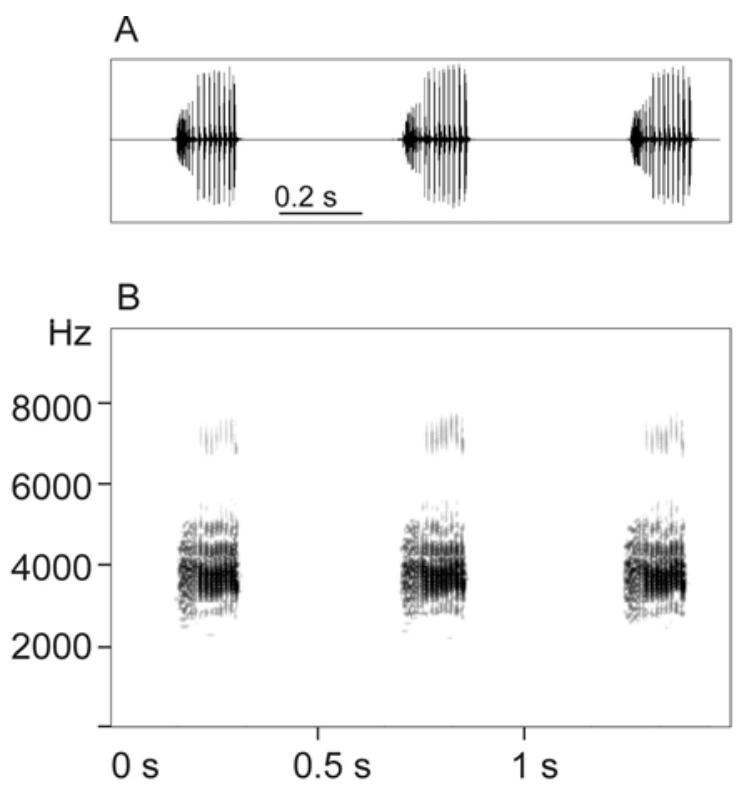

Fig. 1. Advertisement call of Physalaemus henselii (Peters, 1872), ZVCB 11182, Departamento de Rivera, Uruguay, 3 May 2003, air temperature $=8^{\circ} \mathrm{C}$, water temperature $=16^{\circ} \mathrm{C}(\mathrm{A}$, Oscilogram. $\mathrm{B}$, Audiospectrogram). 
Table I. Morphometric and reproductive values for a population of Physalaemus henselii (Peters, 1872) from the North of Uruguay. (Frglt, froglets (sex undetermined frogs); mo, females with mature oocytes; N, number of individuals; OSF, ovarian size factor; srt, month sex ratio (number of females/number of males); SVL, snout-vent length (mm); T, total of individual per month; W, weight (g); wo, females without mature oocytes).

\begin{tabular}{|c|c|c|c|c|c|c|c|c|c|c|c|c|c|c|c|}
\hline \multirow[t]{3}{*}{ Month } & \multicolumn{5}{|c|}{ Males } & \multicolumn{8}{|c|}{ Females } & \multirow{3}{*}{$\frac{\text { Frglt }}{\mathrm{N}}$} & \multirow[t]{3}{*}{$\mathrm{T}$} \\
\hline & \multirow[t]{2}{*}{$\mathrm{N}$} & \multicolumn{2}{|c|}{ W } & \multicolumn{2}{|c|}{ SVL } & \multicolumn{2}{|c|}{$\mathrm{N}$} & \multicolumn{2}{|c|}{ W } & \multicolumn{2}{|c|}{ SVL } & \multirow[t]{2}{*}{ OSF } & \multirow[t]{2}{*}{ srt } & & \\
\hline & & $\bar{x}$ & SD & $\bar{x}$ & $\mathrm{SD}$ & wo & $\mathrm{mo}$ & $\bar{x}$ & SD & $\bar{x}$ & SD & & & & \\
\hline March & 5 & 0.52 & 0.20 & 18.1 & 3.3 & 0 & 0 & & & & & & & 0 & 5 \\
\hline April & 27 & 0.91 & 0.14 & 21.7 & 0.9 & 0 & 18 & 1.11 & 0.17 & 23.6 & 0.7 & 62.3 & 0.67 & 0 & 45 \\
\hline May & 19 & 0.94 & 0.21 & 21.2 & 1.2 & 0 & 29 & 1.22 & 0.24 & 23.5 & 1.3 & 61.9 & 1.53 & 0 & 48 \\
\hline June & 7 & 0.91 & 0.14 & 20.8 & 1.7 & 0 & 9 & 1.13 & 0.28 & 22.8 & 2.0 & 52.4 & 1.29 & 0 & 16 \\
\hline July & 0 & 0 & 0 & 0 & 0 & 0 & 4 & 0.84 & 0.14 & 20.3 & 1.3 & 22.7 & & 0 & 4 \\
\hline August & 0 & 0 & 0 & 0 & 0 & 0 & 1 & 0.65 & & 20.2 & & 32.9 & & 0 & 1 \\
\hline September & 0 & 0 & 0 & 0 & 0 & 0 & 1 & 0.80 & & 22.7 & & 24.9 & & 0 & 1 \\
\hline October & 1 & 0.15 & 0 & 10.7 & 0 & 1 & 0 & 0.26 & & 12.0 & & & 1.00 & 0 & 2 \\
\hline November & 2 & 0.16 & 0.02 & 15.2 & 3.5 & 1 & 0 & 0.10 & & 10.0 & & & 0.50 & 2 & 5 \\
\hline December & 2 & 0.59 & 0.11 & 16.7 & 1.0 & 4 & 0 & 0.37 & 0.12 & 15.2 & 2.4 & & 2.00 & 2 & 8 \\
\hline January & 2 & 0.24 & 0.02 & 13.1 & 0.5 & 2 & 0 & 0.51 & 0.08 & 17.6 & 0.3 & & 1.00 & 0 & 4 \\
\hline February & 4 & 0.45 & 0.08 & 17.9 & 0.1 & 1 & 1 & 0.58 & 0.08 & 19.7 & 3.8 & 40.7 & 0.50 & 1 & 7 \\
\hline TOTAL & 69 & & & & & 9 & 63 & & & & & & & 5 & 146 \\
\hline
\end{tabular}

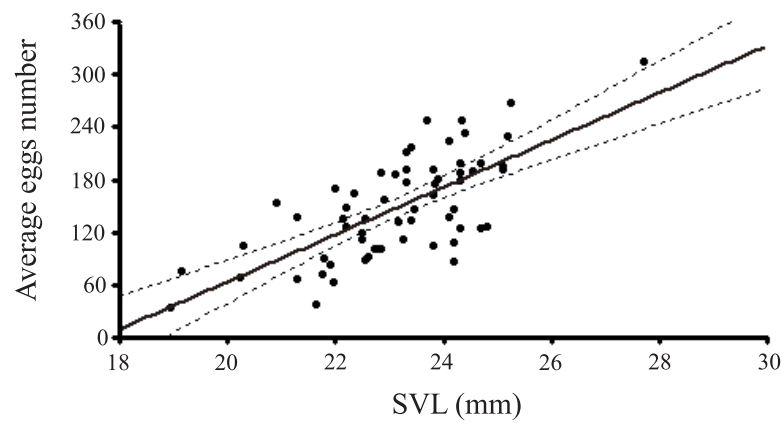

Fig. 2. Regression between Snout-Vent Length (SVL) and Average Eggs Number (AEN), for a sample of Physalaemus henselii (Peters, 1872) from Departamento de Rivera, Uruguay. $\mathrm{AEN}=-475.00+$ $26.94(\mathrm{SVL}) . \mathrm{R}^{2}=0.50 ; \mathrm{F}(1.60)=58.781 ; \mathrm{p}<0.0001$.

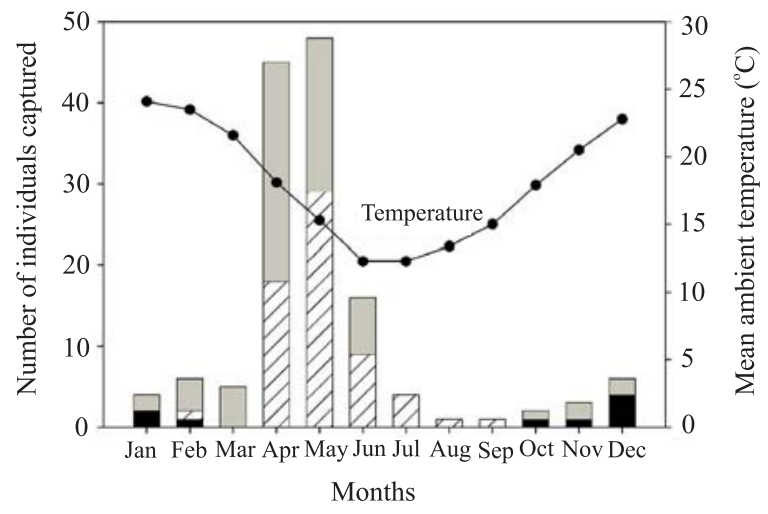

Fig. 3. Number of females with mature oocytes $(\square \backslash)$, without mature oocytes ( $\square$ ) and males $(\square)$ of Physalaemus henselii (Peters, 1872) captured per month, in association with the variation of mean environmental temperature in Departamento de Rivera, Uruguay, along the year. Temperature data from Instituto NACIONAL de Estadística (2002, 2003).

\section{DISCUSSION}

The advertisement call of $P$. henselii analysed herein from northern Uruguay is very similar to the previous description made by BARRIO $(1964,1965)$ from southern Uruguay and Entre Ríos Province, Argentina. The notes of our recordings are somewhat shorter, the pulse rate faster, and the frequency of the bands of maximum acoustic emission are different (as is also between Barrio's sonograms). These differences may be explained by environmental factors and interindividual variability (BLAIR, 1958), and also by different recording methods and analysis. BARRIO (1965) classified the advertisement calls of Physalaemus species into four types. The call of $P$. henselii belongs to the $\mathrm{D}$ type, which is characterized by short, fast, multipulsed and noisy notes, without harmonic structure. This type is very divergent to the others; A type has long notes, with multiple harmonics and initial ascending and then descending frequency modulation; B type has also long notes with reduced harmonics, higher fundamental and ascending frequency modulation; and $\mathrm{C}$ type has short notes with multiple harmonics, and strong descending frequency modulation. The $\mathrm{D}$ type has been recorded in species belonging to different groups, like $P$. centralis Bokermann, 1962 of the $P$. cuvieri Fitzinger, 1826 group, P. henselii of the P. henselii group (BARRIO, 1964, 1965), in most species assigned to the Physalaemus signifer (Girard, 1853) group (BARRIO, 1965; HEYER \& WOLF, 1989; Haddad \& Pombal, 1998) and in Physalaemus rupestris Caramaschi, Carcerelli \& Feio, 1991 (NAScimento et al., 2001) of the $P$. deimaticus Sazima \& Caramaschi, 1988 group (NASCimento et al., 2005). The three species assigned to the $P$. henselii species group, $P$. henselii, $P$. fernandezae and $P$. riograndensis (NASCIMENTO et al., 2005), have different calls; D, B and A type respectively (BARRIO, 1965).

According to our results, Physalaemus henselii has a female sexual cycle with a unimodal distribution of gravid females, which are present from February to September. The ratio "females with mature oocytes / females without mature oocytes" reached the highest values from April to June. This peak is coincident with the reproductive period, which takes place in autumn and early winter. This fact is in agreement with our field observations and previous work: a foam nest was 
collected on 23 April 2002 (Route 27, Departamento de Rivera), calling males and foam nests were observed on 2 and 3 May 2003 (Pueblo Madera, Departamento de Rivera) and calling males were heard on 10 June 1998 (Departamento de Rocha, south-eastern Uruguay; Gambarotta et al., 1999). We conclude that $P$. henselii has one annual reproductive period during the cold season, mainly in autumn and early winter. Our results contrast with both the proposition of a bimodal cycle by BARRIO (1964) and the continuous cycle mentioned by CEI (1980), but we argue that pitfall trapping would have provided a better approximation to the phenological cycle and an unbiased pattern when compared to acoustic surveys, as was found for another Physalaemus species in Uruguay (CAMARGO et al., 2005).

The reproductive period during the cold season is uncommon among anuran species of Uruguay and adjacent areas of Argentina and southern Brazil, it was documented only for P. henselii (BARRIO, 1964; this work), P. fernandezae (BARRIO, 1964) and Pleurodema bibroni Tschudi, 1838 (BARRIO, 1977). Reproductive patterns are correlated with the climatic conditions prevailing in the habitats (JøRGENSEN, 1992). In mesic habitats, breeding is primarily correlated with the seasonal cycle in temperature, while precipitation plays a secondary role, influencing the time of breeding (JøRGENSEN, 1992). In some anuran species, a mechanism that synchronizes the reproductive cycle with the climatic cycle restricts the time of the year in which an ovarian cycle can begin (JøRGENSEN, 1992). The beginning of the reproductive period in $P$. henselii is coincident with the ending of the reproductive period of other sympatric Physalaemus species, like $P$. biligonigerus (Cope, 1861), $P$. riograndensis and $P$. gracilis (Boulenger, 1883) which breed in the warm season (BARRIO, 1965; CEI, 1980; Achaval \& Olmos, 2003; CAmargo et al., 2005). This asynchrony may avoid interspecific overlap at breeding sites. In $P$. henselii, this pattern may also be an adaptation to the availability of water in the wet grasslands where it breeds: visits to the Pueblo Madera localities in October and February (middle spring and summer) revealed complete lack of still water in the places (now turned into pastures) where nests and tadpoles had been found some months earlier. Species that were found sexually active in synchrony and syntopy with $P$. henselii in the studied populations were Hypsiboas pulchellus (Duméril \& Bibron, 1841), Odontophrynus americanus (Duméril \& Bibron, 1841) and Scinax squalirostris (Lutz, 1925). However, these species have a basal reproductive strategy (without foam nests), suggesting low overlap in the "reproductive niche" between them and P. henselii.

In the studied population, the highest peak of activity found in autumn and early winter may be related to reproduction displacement (migration to breeding sites). This increase in activity resulted from abundance of males and gravid females. The abundance peak of males preceded that of females by one month (April vs. May, Fig. 3), and this could be due to an earlier occupation of reproduction sites by males. The second and lesser activity peak that was found in spring and summer, composed by froglets, males and immature females (Fig. 3 ), might be related to dispersion activities following metamorphosis (metamorphosing tadpoles and recently metamorphosed froglets were observed at Pueblo Madera on 9 October 2001) or even movements between alimentary and refuge sites.

The number of oocytes per individual is roughly in agreement with the one reported by BARRIO $(1964 ; 250$ 300 eggs). The positive correlation found between female size and number of mature oocytes is similar to the one observed for many other anuran species (CRUMP, 1974). However, the sex ratio in the studied population has two peaks, one of them (May - June) occurred during the reproductive period and the other (December) overlapped with the period of higher abundance of froglets. Moreover, the female population of the second sex ratio peak differs from the first one, mainly in the maturity of the ovaries and consequently in the values of OSF. Females of the second peak are smaller and immature, a fact that could be interpreted as differential ecological responses of each group. The first group may be composed by the effective reproductive individuals whose activity patterns are related to the amplexus (high values of OSF), and the second group by those females that need to prepare themselves for reproduction. These individuals could not reproduce in the warm season, but may take advantage from the favourable conditions of this period, like high prey availability or minimization of predation risk as by this time the major part of the anuran species of the assemblage is active.

Acknowledgments. We acknowledge A. Camargo for critical review of the manuscript. J. Faivovich and J. Langone made valuable observations to earlier versions of the manuscript. We also thank to D. Naya for valuable help during field work and Compañía Forestal Uruguaya (COFUSA) for partial economical support. FK, CB and MT acknowledge G. Duarte and J. Valbuena for their kind hospitality during field work at Rivera, to M. Lettier for technical support in digitalizing recordings, and G. Pereira for correction of the English language. RM has a doctoral fellowship from Coordenação de Aperfeiçoamento de Pessoal de Nível Superior (CAPES)

\section{REFERENCES}

Achaval, F. \& Olmos, A. 2003. Anfibios y Reptiles del Uruguay. 2ed. Montevideo, Graphis. 136p.

BARrio, A. 1953. Sistemática, morfología y reproducción de Physalaemus henselii (Peters) y Pseudopaludicola falcipes (Hensel). Physis 20:379-389.

1964. Relaciones morfológicas, eto-ecológicas y zoogeográficas entre Physalaemus henseli (Peters) y $P$. fernandezae (Müller) (Anura, Leptodactylidae). Acta Zoológica Lilloana 20:284-305.

1965. El género Physalaemus (Anura, Leptodactylidae) en la Argentina. Physis 25:421-448.

1977. Aportes para la elucidación del "status" taxonómico de Pleurodema bibroni Tschudi y Pleurodema kriegi (Müller) (Amphibia, Anura, Leptodactylidae). Physis 37:311-331.

BAsso, N. 1990. Estrategias adaptativas de una comunidad subtropical de anuros. Cuadernos de Herpetología (Serie Monografías) 1:1-70.

BLAIR, W. F. 1958. Mating call in the speciation of anuran amphibians. American Naturalist 92:27-51.

BokermanN, W. C. A. 1962. Observações biológicas sobre Physalaemus cuvieri Fitz, 1826 (Amphibia, Salientia). Revista Brasileira de Zoologia 22:391-399.

Camargo, A.; Naya, D. E.; Canavero, A.; da Rosa, I. \& Maneyro, R. 2005. Seasonal Activity and the body size-fecundity relationship in a population of Physalaemus gracilis 
(Boulenger, 1883) (Anura, Leptodactylidae) from Uruguay. Annales Zoologici Fennici 42:513-521.

Cardoso, A. J. 1981. Biologia e sobrevivência de Physalaemus cuvieri Fitz., 1826 (Amphibia, Anura) na natureza. Ciencia e Cultura 33:1224-1228.

CEI, J. M. 1980. Amphibians of Argentina. Monitore Zoologico Italiano, (N.S.) Monogr. 2:1-609.

CRUMP, M. L. 1974. Reproductive strategies in a tropical anuran community. Miscellaneous Publications of the Museum of Natural History of the University of Kansas 61:1-68.

Duellman, W. E. \& Crump, M. L . 1974. Speciation in frogs of the Hyla parviceps group in the upper Amazon Basin. Occasional Papers of the Museum of Natural History of the University of Kansas 23:1-40.

Duellman, W. E. \& Trueb, L. 1994. Biology of Amphibians. Baltimore, John Hopkins University. 670p.

Frost, D. R. 2007. Amphibian species of the world: an online reference. Version 5.0 (1 February, 2007). American Museum of Natural History, New York, USA. Available at: <http://research.amnh.org/herpetology/amphibia/index.php>. Accessed on: 10.06.2007.

Gambarotta, J. C.; Saralegui, A. \& González, E. M. 1999. Vertebrados tetrápodos del refugio de fauna Laguna de Castillos, Departamento de Rocha. Relevamientos de Biodiversidad 3:1-31.

Giaretta, A. A. \& Menin, M. 2004. Reproduction, phenology, and mortality sources of a species of Physalaemus (Anura, Leptodactylidae). Journal of Natural History 38:1711-1722.

Haddad, C. F. B. \& Pombal, J. P. 1998. Redescription of Physalaemus spiniger (Anura: Leptodactylidae) and description of two new reproductive modes. Journal of Herpetology 32:557-565.

Heyer, W. R.; Rand, A. S.; Cruz, C. A. G.; Peixoto, O. L. \& Nelson, C. E. 1990. Frogs of Boracéia. Arquivos de Zoologia 31: $237-410$.

Heyer, W. R. \& Wolf, A. J. 1989. Physalaemus crombiei
(Amphibia: Leptodactylidae), a new frog species from Espírito Santo, Brazil with comments on the $P$. signifer group. Proceedings of the Biological Society of Washington 102:500-506.

Instituto Nacional de Estadística. 2002. Anuario Estadístico 2002. Información General: Clima. Available at: <http:// www.ine.gub.uy/biblioteca/anuario2002/anuario.swf>. Accessed on: 08.02 .2008

2003. Anuario Estadístico 2003. Información General: Clima. Available at: <http://www.ine.gub.uy/biblioteca/ anuario2003/anuario\%20web.swf $>$. Accessed on: 08.02.2008.

Jørgensen, C. B. 1992. Growth and reproduction. In: Feder, M. E. \& Burggren, W. W. eds. Environmental Physiology of the Amphibians. Chicago, University of Chicago. p.439-466.

Nascimento, L. B.; Caramaschi, U. \& Cruz, C. A. G. 2005. Taxonomic review of the species groups of the genus Physalaemus Fitzinger, 1826 with revalidation of the genera Engystomops Jiménez de la Espada, 1872 and Eupemphix Steindachner, 1863 (Amphibia, Anura, Leptodactylidae). Arquivos do Museu Nacional 63(2):297-320.

Nascimento, L. B.; Carvalho, R. R; Wogel, H.; Fernandes, D. S. \& Feio, R. N. 2001. Reprodução e descrição do girino de Physalaemus rupestris Caramaschi, Carcerelli \& Feio, 1991 (Amphibia, Anura, Leptodactylidae). Boletim do Museu Nacional (N. S.) Zoologia 450:1-12.

Nomura, F.; Rossa-Feres, D. De C. \& Do Prado, V. H. M. 2003. The tadpole of Physalaemus fuscomaculatus (Anura: Leptodactylidae), with a description of internal oral morphology. Zootaxa 370:1-8.

Pimenta, B. V. S. \& Cruz, C. A. G. 2004. The tadpole and advertisement call of Physalaemus aguirrei Bokermann, 1966 (Amphibia, Anura, Leptodactylidae). Amphibia-Reptilia 25: 197-204.

Wogel, H.; Abrunhosa, P. A. \& Pombal, J. P. 2002. Atividade reprodutiva de Physalaemus signifer (Anura, Leptodactylidae) em ambiente temporário. Iheringia, Série Zoologia, 92:57-70.

Recebido em dezembro de 2005. Aceito em outubro de 2007. ISSN 0073-4721

Artigo disponível em: www.scielo.br/isz 